\title{
India shuts door on embryonic export market
}

\section{K. S. Jayaraman, New Delhi}

Fears that India's booming assisted-fertility industry could become a source of human embryonic stem (ES) cells have prompted the country's medical authorities to propose a ban on the export of all human embryonic material.

The Indian Council of Medical Research (ICMR), a government-funded body that coordinates biomedical research, last week released new draft guidelines aimed at preventing the misuse of human embryos stored at the hundreds of unregulated fertility clinics that have sprung up in India over the past ten years. The new rules will prohibit the export of any part of an embryo, and stipulate that couples may only donate, and not sell, embryos to researchers inside India.

T. C. Anandkumar, research director of the Hope Fertility Clinic in Bangalore and a former ICMR director, was involved in drafting the guidelines. He says that the council has reacted to fears that restrictive embryoresearch regulation in Europe and the United States could force scientists to look abroad for embryonic material. Some Indian clinics say that they have already been approached by Western researchers wishing to obtain human ES cells.

Whether European and US researchers would want to risk the bad publicity associated with obtaining stem cells from an unregulated clinic in a developing country is unclear. Germany allows research to be carried out only on imported ES cells, but these must be obtained from certain approved cell lines. And US researchers, who are free to obtain stem cells from fertility clinics as long their work is not federally funded, say that they have no problem in obtaining embryonic material.

The new guidelines could, however, cause problems for Indian researchers. "Prohibiting the transfer of embryos could virtually prevent us from collaborating with foreign agencies," says Mitradas Panicker, a neurobiologist at the National Centre for Biological Sciences in Bangalore, one of two Indian laboratories that the US National Institutes of Health lists as providing ES-cell lines with which federally funded researchers are permitted to work (see Nature 412, 665; 2001). Panicker says that collaborations with US scientists would suffer "if the guidelines failed to make a distinction between selling embryos for money and transferring them for research".

The owner of the other ES cells on the NIH list, Reliance Life Science in Mumbai, faces similar problems. The company says that it has developed a cell line that differentiates into insulin-producing pancreatic cells that could be used to treat diabetes, and is ready to begin animal trials. "We have several

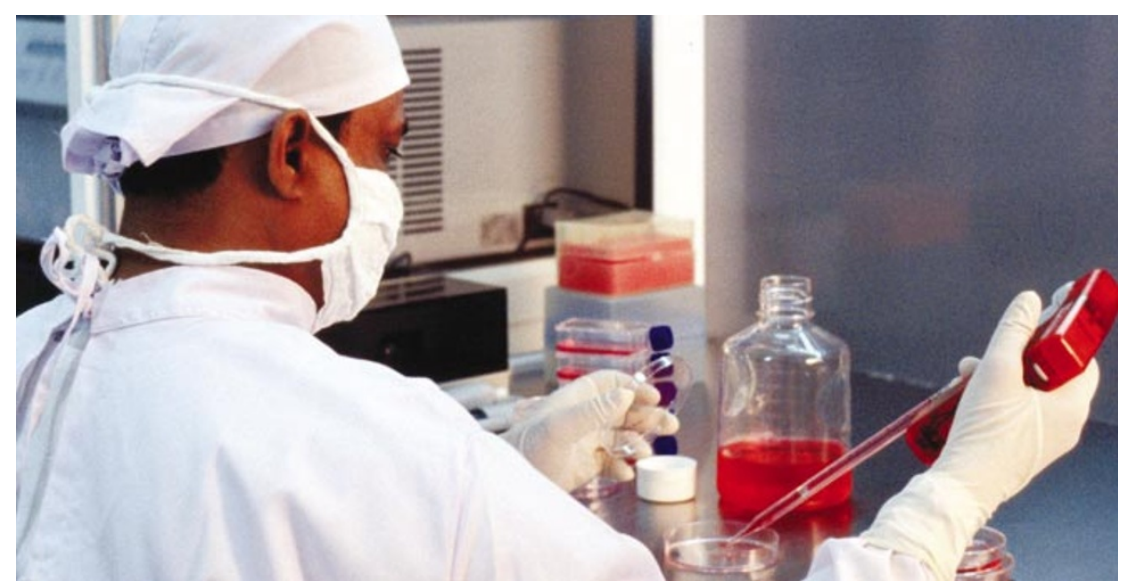

Stem-cell researcher Satish Totey fears that a ban on embryo exports may harm collaborative projects.

foreign collaborations planned with our cell lines, but as the guidelines stand today we cannot do any collaborative research," says Satish Totey, the company's head of ES-cell research.

The guidelines may yet be refined before a final version is presented to the government. The National Accreditation Authority, a new body that is currently being set up to administer the guidelines, says that it will consider suggested amendments from the scientific community until the end of December.

\section{Telescope to track speedy satellites}

\section{Geoff Brumfiel, Washington}

Plans for a new military satellite-tracking telescope could help astronomers spot unusual changes in the night sky.

The 3-metre Space Surveillance Telescope (SST), a US\$65-million project overseen by the Defense Advanced Research Projects Agency (DARPA), part of the Pentagon, is designed to improve the US Air Force's ability to monitor satellites and orbiting space debris. Work on the telescope's detectors is set to begin in October and the telescope should be complete by 2008 .

Building a telescope that can scan the sky rapidly for fast-moving satellites will

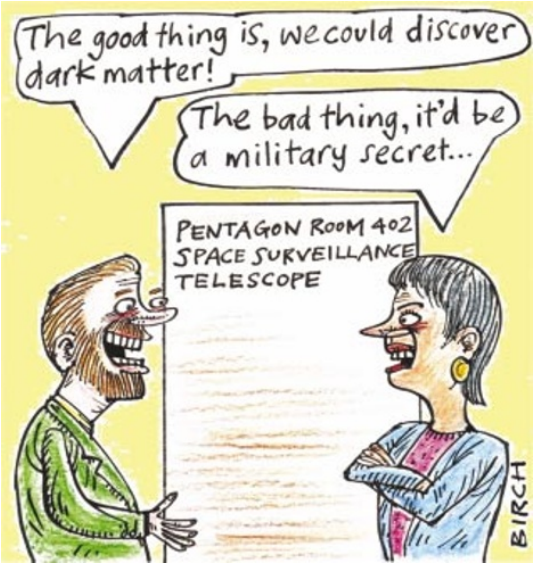

require some unusual technology, according to Timothy Grayson, who oversees the SST project at DARPA's Special Projects Office in Arlington, Virginia. Most telescopes use two mirrors to focus light onto detectors, but the SST will add an extra mirror to reduce distortion around the edge of its images, effectively widening the field of view. The three-mirror system will be difficult to set up, says Grayson. The design will also require the development of new, curved charge-coupled device detectors to capture digital images from the telescope.

The telescope's primary client is likely to be the military, but some data may be made available to researchers. The broad field of view and sensitive detector could, for example, help astronomers search for stars of variable brightness. Grayson has met officials from NASA and the National Science Foundation (NSF) to discuss how the telescope could benefit future research.

Civilian use of military telescopes is not unprecedented, says Jim Breckinridge, programme director for Advanced Technologies and Instrumentation at the NSF's Division of Astronomical Sciences in Arlington, Virginia. His office has an agreement with the Air Force Office of Scientific Research that allows scientists to use the Air Force's 3.67-metre Advanced Electro-Optical System telescope in Hawaii. 